\title{
ks. Wojciech Góralski, Błąd co do przymiotu osoby a nieważność małżeństwa kanonicznego (kan. 1097 S 2 KPK), Płock 2012, ss. 334
}

Kolejna już publikacja książkowa ks. prof. W. Góralskiego - wybitnego polskiego kanonisty, dotycząca małżeńskiego kanonicznego prawa małżeńskiego, jest znakomitą monografią na temat kan. $1097 \$ 2$, czyli na temat błędu co do przymiotu osoby, skutkującego nieważnością małżeństwa kanonicznego. Została ona opublikowana przez Płocki Instytut Wydawniczy.

Monografia została podzielona na dwie części. Pierwsza nosi tytuł „Kształtowanie się doktryny, orzecznictwa i ustawodawstwa w przedmiocie error facti” i obejmuje sześć rozdziałów (s. 17-180), poświęconych poszczególnym okresom rozwoju kanonistyki matrymonialnej, w których kształtowały się i ścierały różne kierunki interpretacyjne; natomiast część druga obejmuje tylko trzy rozdziały i nosi tytuł „Kan. $1097 \$ 2$ KPK - aspekt substancjalny i dowodowy" (s. 181-302) i zawiera analizę prawną rozważanej normy kanonicznej oraz omawia dowodzenie dotyczące „error qualitatis directe et principaliter intentae”. Każdy z dziewięciu rozdziałów zawiera wprowadzenie oraz uwagi końcowe; także krótkie wprowadzenia rozpoczynają wymienione dwie części monografii. Ponadto na monografię składają się: Spis treści (s. 5-7), Wykaz skrótów (s. 8), Wstęp (s. 9-14), Zakończenie (s. 303-310) oraz obszerna Bibliografia (311-330). Na końcu publikacja zawiera także spis treści w języku włoskim (s. 331-334).

We Wstępie do publikacji czytamy m.in., że w dziedzinie kanonicznego prawa małżeńskiego obszarem centralnym pozostaje zgoda małżeńska, która stanowi przyczynę sprawczą przymierza mężczyzny oraz kobiety. „Brak lub wady konsensu małżeńskiego stanowią m.in. błędy: dotyczące faktu lub prawa (facti vel iuris), określone w kan. 1097-1099 obowiązującego KPK. Do błędów dotyczących faktu należą: błąd co do osoby (kan. $1097 \$ 1$ KPK), błąd co do przymiotu osoby zamierzony bezpośrednio i zasadniczo (kan. $1097 \$ 2$ $\mathrm{KPK}$ ) oraz błąd co do przymiotu osoby, który może poważnie zakłócić wspólnotę życia małżeńskiego, spowodowany podstępem (kan. 1098 KPK). Natomiast kan. 1099 KPK poświęcony jest błędowi tzw. prawnemu, którego przedmiotem jest jedność, nierozerwalność lub godność sakramentalna małżeństwa” (s. 9). Sukcesywnie ks. prof. W. Góralski 
wskazał, że pierwsza część jego monografii ma charakter historyczny, obejmujący kilka etapów - konkretnie od Dekretu Gracjana do kodeksu z 1983 roku - kształtowania się doktryny, orzecznictwa oraz ustawodawstwa na temat wpływu błędu co do przymiotu osoby na ważność małżeństwa kanonicznego, przy czym zaznaczył, że jego studium zostało oparte na wcześniejszych badaniach innego autora (zob. S. Zvolenský, „Error qualitatis dans causam” e „error qualitatis directe et principaliter intentae”. Studio storico della distinzione, Roma 1998). Z kolei druga część publikacji została poświęcona aspektowi substancjalnemu i procesowemu kan. $1097 \$ 2 \mathrm{KPK}$; „opracowanie ma zatem charakter studium historyczno-dogmatycznoprawnego, w którym nawiązuje się zarówno do doktryny, jak i do orzecznictwa rotalnego" (s. 14).

Rozdział I „Okres klasyczny (XII-XIII w.)” ukazuje pierwotną myśl kanonistyczną w przedmiocie błędu co do przymiotu osoby w zakreślonym okresie czasowym (s. 17-42). W kolejności ks. prof. W. Góralski przedstawił poglądy mistrza Gracjana, Piotra Lombarda, dekretystów oraz dekretalistów, św. Tomasza z Akwinu, św. Bonawentury, Ryszarda z Mediavilla, aby zakończyć na myśli prawnej Dekretałów Grzegorza IX oraz dekretalistyki klasycznej.

Rozdział II „Okres poklasyczny (od połowy XIV do końca XVI w.)” kontynuuje przedstawianie myśli kanonistycznej w przedmiocie monografii (s. 43-69). Zostały w nim przedstawione poglądy rozwijające dotychczasowe osiągnięcia na temat błędu co do przymiotu osoby następujących autorów: Antoniego z Asti, Raniera Giordaniego z Pisy, Alberyka z Rosaty, św. Antonina z Florencji, Angela z Chiavasso, Jana Chrzciciela Trovamali, Jana Cagnazza, Sylwestra Mazzoliniego, Dominika de Soto, Jana Mediny oraz ogólnie kanonistów schyłku XVI stulecia.

Rozdział III (s. 70-105) oraz sukcesywny Rozdział IV (s. 106-125) przedstawiają poglądy kanonistyczne w materii błędu co do przymiotu osoby odpowiednio w siedemnastym oraz osiemnastym stuleciu. I tak spośród autorów siedemnastowiecznych zostały wymienione poglądy Tomasza Sáncheza oraz Bazylego Ponce de León; natomiast gdy idzie o poglądy autorów osiemnastowiecznych, to ks. prof. W. Góralski wyodrębnił trzy następujące tematy: stanowisko odmawiające błędowi co do przymiotu osoby mocy unieważniającej, stanowisko przyznające błędowi co do przymiotu osoby moc unieważniającą oraz doktrynę św. Alfonsa Liguoriego.

Rozdział V nosi tytuł „Ewolucja doktryny i orzecznictwa w przedmiocie waloru prawnego error qualitatis od połowy XIX w. do KPK z 1917 r.”. Konkretnie rozdział ten (s. 126152) analizuje okres poprzedzający kodyfikację z 1917 roku, ustawodawstwo Kodeksu prawa kanonicznego z 1917 roku, w szczególności kan. $1083 \$ 2$ nr 1, oraz jego recepcję w doktrynie oraz orzecznictwie rotalnym. 
Rozdział VI, ostatni z pierwszej części monografii (s. 153-180), nosi tytuł „Od wyroku c. Canals (21.04.1970) do kan. 1097 \$ 2 KPK z 1983 roku” i omawia właśnie wspomniany wyrok rotalny „coram Canals”, jego oddźwięk w sukcesywnym orzecznictwie rotalnym oraz kształtowanie się aktualnego kan. $1097 \$ 2$ w pracach Papieskiej Komisji do Rewizji Kodeksu prawa kanonicznego.

Kolejny rozdział monografii, czyli pierwszy w jej drugiej części, zawiera analizę aktualnego kan. $1097 \$ 2$ KPK (s. 183-216). Została ona zawarta w następujących zagadnieniach: błąd, przedmiot błędu, brak skuteczności unieważniającej error causam dans, skuteczność unieważniająca błędu co do przymiotu zamierzonego bezpośrednio i zasadniczo.

Następny rozdział (s. 217-261) nosi tytuł „Źródło skuteczności unieważniającej błędu co do przymiotu zamierzonego bezpośrednio i zasadniczo oraz mechanizm unieważniający” i prezentuje w tym przedmiocie dwa zagadnienia. Pierwsze dotyczy doktryny, drugie natomiast orzecznictwa rotalnego.

Ostatni rozdział monografii został poświęcony dowodzeniu błędu co do przymiotu zamierzonego bezpośrednio i zasadniczo (s. 262-302). Ksiądz prof. W. Góralski skupił się w nim na dwóch zagadnieniach, pierwszym jest przedmiot oraz sposób dowodzenia, drugim natomiast jest wskazanie ważniejszych problemów w rozstrzygnięciu spraw nullitatis matrimonii z kan. 1097 \$ KPK w orzecznictwie rotalnym.

W Zakończeniu monografii, w nawiązaniu do kan. 1097 \$ 2 K K, czytamy między innymi, że posoborowy ustawodawca powszechny „zdecydował się na zapis, w myśl którego - w nawiązaniu do trzeciej reguły św. Alfonsa Liguoriego - error qualitatis, chociażby był przyczyną zawarcia małżeństwa, nie powoduje nieważności małżeństwa, chyba że przymiot ten został bezpośrednio i zasadniczo zamierzony" (s. 303).

Konkludując, należy stwierdzić, że mamy do czynienia z bardzo wartościowym i opartym na bogatym materiale źródłowym oraz na orzecznictwie Roty Rzymskiej studium kan. $1097 \$ 2 \mathrm{KPK}$; trzeba podkreślić, że jest to całościowe oraz metodologicznie klarowne naukowe studium wyszczególnionej normy prawnej. Obrana tematyka badawcza jasno wskazała, że dopiero obowiązująca norma prawna winna być uznana za właściwe rozwiązanie problemu od dawna obecnego w doktrynie oraz sądownictwie Kościoła. Niewątpliwie podział monografii na dwie części, czyli na część o charakterze historyczno-doktrynalnym oraz na część o charakterze prawno-dowodowym jest jak najbardziej uzasadniony, gdyż jak pisze sam Autor, bogata historia kształtowania się doktryny w odniesieniu do błędu co do przymiotu osoby wymownie wskazuje, jak znaczący to był problem, który przez stulecia usiłowano właściwie rozwiązać (s. 303). Nie ulega wątpliwości, że nowa monografia ks. prof. W. Góralskiego jest jego kolejnym znaczącym wkładem w rozwój polskiej kanonistyki 
ks. Tomasz Rozkrut

i stanowi jednocześnie kompetentną pomoc i ważny wzorzec naukowy dla innych kanonistów, w szczególności zaś dla sądownictwa kościelnego, jak należy właściwie interpretować kan. 1097 \$ 2 k kodeksu Jana Pawła II.

ks. Tomasz Rozkrut 